\title{
Nanostructured superhydrophobic films synthesized by electrodeposition of fluorinated polyindoles
}

\author{
Gabriela Ramos Chagas, Thierry Darmanin and Frédéric Guittard
}

\author{
Full Research Paper \\ Address: \\ Univ. Nice Sophia Antipolis, CNRS, LPMC, UMR 7336, 06100 Nice, \\ France; Fax: (+33)492076156; Tel: (+33)492076159

\section{Email:} \\ Frédéric Guittard ${ }^{*}$ - guittard@unice.fr \\ * Corresponding author \\ Keywords: \\ bioinspiration; conducting polymers; electrochemistry; nanostructures; \\ polyindoles; superhydrophobic \\ Beilstein J. Nanotechnol. 2015, 6, 2078-2087. \\ doi:10.3762/bjnano.6.212 \\ Received: 01 August 2015 \\ Accepted: 08 October 2015 \\ Published: 28 October 2015 \\ This article is part of the Thematic Series "Organized films". \\ Guest Editor: M. Canepa \\ (c) 2015 Ramos Chagas et al; licensee Beilstein-Institut. \\ License and terms: see end of document.
}

\begin{abstract}
Materials with bioinspired superhydrophobic properties are highly desirable for many potential applications. Here, nine novel monomers derived from indole are synthesized to obtain these properties by electropolymerization. These monomers differ by the length $\left(\mathrm{C}_{4} \mathrm{~F}_{9}, \mathrm{C}_{6} \mathrm{~F}_{13}\right.$ and $\left.\mathrm{C}_{8} \mathrm{~F}_{17}\right)$ and the position (4-, 5- and 6-position of indole) of the perfluorinated substituent. Polymeric films were obtained with $\mathrm{C}_{4} \mathrm{~F}_{9}$ and $\mathrm{C}_{6} \mathrm{~F}_{13}$ chains and differences in the surface morphology depend especially on the substituent position. The polyindoles exhibited hydrophobic and superhydrophobic properties even with a very low roughness. The best results are obtained with PIndole-6-F $\mathbf{F}_{\mathbf{6}}$ for which superhydrophobic and highly oleophobic properties are obtained due to the presence of spherical nanoparticles and low surface energy compounds.
\end{abstract}

\section{Introduction}

The number of studies about materials with superhydrophobic properties, characterized by extremely high water contact angles $\left(\theta_{\mathrm{w}}\right)$ and low water adhesion or hysteresis (also known as "Lotus effect"), grows exponentially because of the importance for both the scientific and industrial community [1-6]. Superhydrophobic properties are quite common in nature, in both animals and plants, and allow them surviving against predators or hostile environments such as extremely humid or dry regions, for example [7-12]. Bioinspiration has shown the importance of developing structured surfaces in the presence of low surface energy materials that allow one to obtain more easily superhydrophobic properties with higher robustness [13-15]. Controlling the surface energy and the roughness is hence fundamental to achieve the superhydrophobicity.

All kind of materials can be used to reach superhydrophobicity, but conducting polymers have many advantages such as an easiness to functionalize and opto-electronic properties [16] with the possibility to introduce various dopants (smart materials) $[17,18]$. Conducting polymers are also exceptional materials for 
the control of surface nanostructures and wettability. First of all, nanostructures of extremely various shapes can be produced in solution by self-assembly [19-21] or directly formed on substrates by different strategies such as preferential growth [22], grafting [23], vapor phase polymerization [24], plasma polymerization [25] and electropolymerization [26-30]. The last method allows for a very quick and easy deposition of conducting polymer films while the formation of surface structures can be controlled by electrochemical parameters [26] and the used monomer [27]. In order to control the formation of surface nanostructures, the core responsible for the polymerization (such as thiophene, pyrrole or 3,4-ethylenedioxythiophene) [27-30] is probably the most important parameter. Then, the polymer can also be controlled by introducing hydrophobic/ hydrophilic substituents or dopant agents [17,18,27-30]. In most of the cases, fluorocarbon or hydrocarbon chains were used to reach superhydrophobic properties.

Here, we report for the first time the formation of superhydrophobic properties from indole derivatives. Nine novel indole monomers substituted by fluorocarbon chains of different length $\left(\mathrm{C}_{4} \mathrm{~F}_{9}, \mathrm{C}_{6} \mathrm{~F}_{13}\right.$ and $\left.\mathrm{C}_{8} \mathrm{~F}_{17}\right)$ and in different positions (4-, 5and 6-position of indole) were synthesized and electropolymerized (Scheme 1). We report the influence of the fluorocarbon chain length and the substituent position on the surface morphology and hydrophobicity.

\section{Results and Discussion Electrodeposition}

In order to develop structured polymeric films, the monomers were electropolymerized. First of all, it was necessary to determine the oxidation potential $\left(E^{\mathrm{ox}}\right)$ of all the monomers. These $E^{\mathrm{ox}}$ were determined by cyclic voltammetry and were found to be in the range of $0.9-1.3 \mathrm{~V}$ vs SCE for the functionalized monomers, as shown in Table 1. A cyclic voltammogram for Indole-6-F $\mathbf{F}_{\mathbf{6}}$ is shown in Figure 1, where it is possible to see the maximum peak of oxidation of the monomer. Then, the polymerization was followed from $-0.7 \mathrm{~V}$ to a potential slightly lower than $E^{\mathrm{ox}}$ (working potential $E^{\mathrm{w}}$ ) by the same electrochemical method. Examples of cyclic voltammograms for the polyindoles are presented in Figure 2.

\begin{tabular}{|c|c|c|}
\hline monomer & $\begin{array}{l}\text { oxidation potential } \\
E^{\mathrm{OX}}(\mathrm{V})\end{array}$ & $\begin{array}{c}\text { working potential } \\
E^{\mathrm{w}}(\mathrm{V})\end{array}$ \\
\hline Indole & 1.64 & 1.56 \\
\hline Indole-4-F 4 & 1.30 & 1.23 \\
\hline Indole-5-F 4 & 1.31 & 1.26 \\
\hline Indole-6-F 4 & 1.13 & 1.08 \\
\hline Indole-4-F 6 & 1.19 & 1.13 \\
\hline Indole-5-F 6 & 1.15 & 1.10 \\
\hline Indole-6-F 6 & 1.07 & 1.03 \\
\hline Indole-4-F8 & 1.14 & 1.08 \\
\hline Indole-5-F 8 & 1.06 & 1.01 \\
\hline Indole-6-F 8 & 0.99 & 0.96 \\
\hline
\end{tabular}

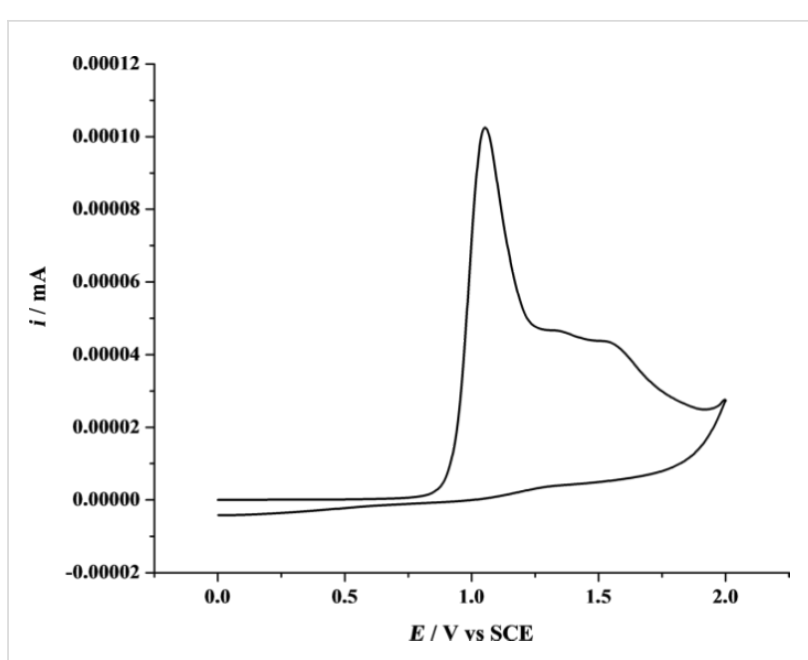

Figure 1: Cyclic voltammogram of the monomer Indole-6- $\mathrm{F}_{\mathbf{6}}$ (1 scan at $20 \mathrm{mV} \cdot \mathrm{s}^{-1}$ ). Electropolymerization in $0.1 \mathrm{M}$ of acetonitrile/Bu $\mathrm{NClO}_{4}$.<smiles>O=C(CC[14CH2][14CH](F)F)NCc1cccc2[nH]ccc12</smiles>

4-Indole-F<smiles>O=C(CC[14CH2][14CH](F)F)NCc1ccc2[nH]ccc2c1</smiles>

5-Indole- $F_{n}$<smiles></smiles>

6-Indole- $F_{n}$ 

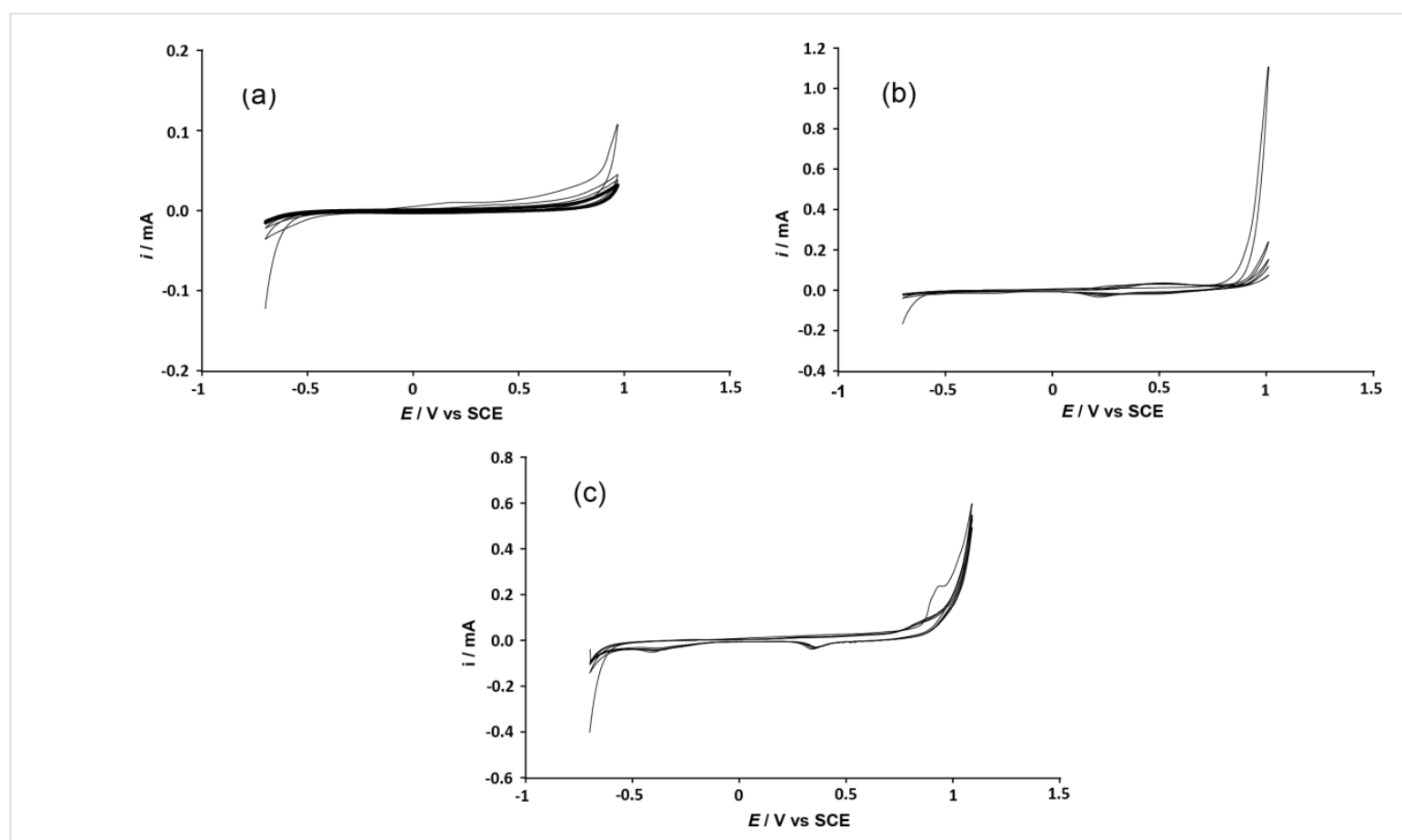

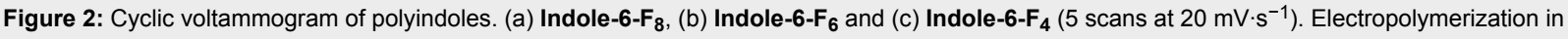
$0.1 \mathrm{M}$ of acetonitrile/ $\mathrm{Bu}_{4} \mathrm{NClO}_{4}$.

These cyclic voltammograms show only little variation in the polymer oxidation and reduction peaks due to the low conductivity of the polymers. Also, the short length of the new oligomers formed during the electropolymerization process increases their solubility resulting in polymeric films with a very low thickness. This may be explained by the reaction of amine groups of indole with the $\mathrm{H}^{+}$ions released during the electropolymerization process. For these reasons, the deposition method has been changed and the depositions have been then performed at constant potential and using different normalized deposition charges, $Q s$, (from 0 to $100 \mathrm{mC} \cdot \mathrm{cm}^{-2}$ ) in order to better control the amount of polymer electrodeposited. However, polymeric films were obtained with all the monomers except that with $\mathrm{C}_{8} \mathrm{~F}_{17}$ chains because their large size induced very huge steric hindrances during the reaction and the polymerization is not favorable.

\section{Surface structures and wettability}

The surface structures were characterized by scanning electron microscopy (SEM) and surface roughness measurements. The SEM images for $Q s=100 \mathrm{mC} \cdot \mathrm{cm}^{-2}$ are given in Figure 3 and Figure 4 and the surface roughness measurements can be found in Table 2. First of all, the surfaces are not very rough, however differences were observed especially with the substituent positions. Even if some craters are observed on PIndole-4-F 6 , the substitution in the 4-position gives the less structured surfaces. By contrast, nanofibers are observed with the substituents in the 5-position (PIndole-5-F $\boldsymbol{n}$ ) and spherical particles in the 6-position (PIndole-6-F $\boldsymbol{F}_{\boldsymbol{n}}$ ). This confirms previous works in which authors showed that the polymerization is favorable in the indole positions 2, 3, 5 and 7 [31,32]. Indeed, if the polymerization of indole is more favorable in certain positions, the location of the substituent may influence the polymerization and the way in which the monomers are linked to one another forming different structures. This work is also in agreement with the literature where the authors showed that due to preferable polymerization positions on indole, fiber structures can be obtained by interfacial polymerization because the polymerization is directional, while spheres are obtained when the polymerization is equal in all directions [33]. In this case, the polymerization of the fluorinated indoles seems to be directional for PIndole-5-F $\boldsymbol{F}_{\boldsymbol{n}}$ and proceeds equally in all directions for PIndole-6-F $\boldsymbol{n}_{\boldsymbol{n}}$. For PIndole-4-F $\boldsymbol{n}$, the polymerization should not be favorable to form any structure on the surface. Previous works showed that one of the main parameters governing the surface roughness is the solubility of the oligomers formed in the first instance [26,34]. Hence, higher roughness of PIndole-6-F $\boldsymbol{n}$ can be explained by the formation of longer polymer chains. PIndole-5-F $\mathbf{4}$ and PIndole-6-F 4 also showed an increase in roughness for normalized charges of 50 and $100 \mathrm{mC} \cdot \mathrm{cm}^{-2}$ without significant changes in the wettability comparing the others polyindoles. In contrast, PIndole-4-F 6 showed the same tendency as the other polymers in terms of conserving the same wettability even if their roughness only 
Table 2: Arithmetic roughness $\left(R_{\mathrm{a}}\right)$, quadratic roughness $\left(R_{\mathrm{q}}\right)$ and apparent contact angles $(\theta)$ for the four probe liquids (water, diiodomethane, sunflower oil and hexadecane) for the polymers as a function of the normalized deposition charge.

\begin{tabular}{|c|c|c|c|c|c|c|c|}
\hline polymer & $\begin{array}{l}\text { normalized deposition } \\
\text { charge }\left(\mathrm{mC} \cdot \mathrm{cm}^{-2}\right)\end{array}$ & $R_{\mathrm{a}}(\mathrm{nm})$ & $R_{\mathrm{q}}(\mathrm{nm})$ & $\theta_{\text {water }}$ & $\theta_{\text {diiodomethane }}$ & $\theta_{\text {sunflower }}$ & $\theta_{\text {hexadecane }}$ \\
\hline \multirow{4}{*}{ PIndole } & 12.5 & 13.0 & 15.9 & 73.2 & 30.5 & 13.3 & 0 \\
\hline & 25 & 10.8 & 13.2 & 71.5 & 25.3 & 12.0 & 0 \\
\hline & 50 & 14.3 & 16.9 & 71.5 & 23.0 & 14.6 & 0 \\
\hline & 100 & 21.9 & 31.0 & 69.8 & 27.2 & 10.9 & 0 \\
\hline \multirow{4}{*}{ PIndole-4-F 6} & 12.5 & 15.5 & 19.5 & 109.2 & 83.1 & 57.7 & 65.1 \\
\hline & 25 & 12.9 & 15.8 & 110.0 & 89.3 & 65.7 & 69.3 \\
\hline & 50 & 12.7 & 15.2 & 112.4 & 88.8 & 77.0 & 72.4 \\
\hline & 100 & 45.2 & 65.4 & 109.9 & 82.3 & 68.1 & 72.0 \\
\hline \multirow{4}{*}{ PIndole-5-F 6} & 12.5 & 8.7 & 13.4 & 117.1 & 98.7 & 78.8 & 75.3 \\
\hline & 25 & 9.5 & 19.0 & 116.3 & 100.7 & 92.5 & 73.8 \\
\hline & 50 & 8.5 & 18.1 & 122.1 & 99.8 & 96.8 & 77.5 \\
\hline & 100 & 17.7 & 31.2 & 124.8 & 103.3 & 87.0 & 74.8 \\
\hline \multirow{4}{*}{ PIndole-6-F 6} & 12.5 & 17.5 & 25.3 & 146.5 & 106.5 & 92.1 & 79.8 \\
\hline & 25 & 11.6 & 18.3 & 149.3 & 111.3 & 86.9 & 87.7 \\
\hline & 50 & 22.1 & 33.4 & 159.0 & 116.3 & 107.1 & 93.3 \\
\hline & 100 & 26.3 & 38.9 & 158.9 & 117.6 & 107.3 & 92.6 \\
\hline \multirow{4}{*}{ PIndole-4-F 4} & 12.5 & 17.0 & 20.8 & 96.7 & 75.2 & 39.6 & 45.6 \\
\hline & 25 & 16.5 & 20.2 & 99.5 & 83.3 & 59.4 & 52.3 \\
\hline & 50 & 16.6 & 19.6 & 100.2 & 78.8 & 53.4 & 60.3 \\
\hline & 100 & 15.4 & 18.9 & 98.7 & 78.1 & 59.6 & 43.4 \\
\hline \multirow{4}{*}{ PIndole-5-F 4} & 12.5 & 36.8 & 50.2 & 107.6 & 85.7 & 68.0 & 48.8 \\
\hline & 25 & 50.2 & 67.0 & 106.4 & 86.9 & 84.6 & 74.4 \\
\hline & 50 & 117.0 & 158.9 & 108.4 & 85.7 & 70.2 & 61.4 \\
\hline & 100 & 150.6 & 194.2 & 106.0 & 92.6 & 75.0 & 71.1 \\
\hline \multirow{4}{*}{ PIndole-6-F 4} & 12.5 & 76.1 & 99.8 & 127.1 & 114.9 & 97.1 & 88.6 \\
\hline & 25 & 71.5 & 98.8 & 142.9 & 122.7 & 106.7 & 97.7 \\
\hline & 50 & 174.5 & 243.3 & 133.1 & 119.5 & 103.3 & 93.3 \\
\hline & 100 & 153.3 & 202.9 & 131.2 & 120.2 & 100.8 & 93.4 \\
\hline
\end{tabular}

exhibited a significant increase at a normalized charge of $100 \mathrm{mC} \cdot \mathrm{cm}^{-2}$.

The wettability properties (Table 2 ) are in agreement with the SEM images. The polymers PIndole-4-F $\boldsymbol{n}$ are just slightly hydrophobic confirming the low effect of the surface structures for these polymers, independent of the fluorinated chain size. The polymers PIndole-5-F $\boldsymbol{n}$ are more hydrophobic with apparent water contact angles $\left(\theta_{\text {water }}\right)$ of $124.8^{\circ}$ for a normalized deposition charge of $100 \mathrm{mC} \cdot \mathrm{cm}^{-2}$. Here, the contact angles are not very high because the nanofibers are horizontally aligned on the substrate. By contrast, the polymers PIndole-6-F $\boldsymbol{n}$ display extremely high $\theta_{\text {water }}$ and also superhydrophobic properties for PIndole-6-F 6 , even with a low rough- ness. The differences between the $\theta_{\text {water }}$ for the $\mathrm{C}_{6} \mathrm{~F}_{13}$-polyindoles can be seen in Figure 5. Indeed, not only $\theta_{\text {water }}$ of $159.0^{\circ}$ were measured on this polymer, but also highly oleophobic properties with $\theta_{\text {hexadecane }}=93.3^{\circ}$. Moreover, the polymer presents extremely low hysteresis and sliding angles for normalized charges of 50 and $100 \mathrm{mC} \cdot \mathrm{cm}^{-2}$, as shown in Table 3. For all polymers, the wettability changed with the position of the substituent on indole due to the differences in the structuration and with the increase of the length of the fluorinated chains. The different normalized charges did not result in large variations of wettability for any probe liquid, however, the highest normalized charge $\left(100 \mathrm{mC} \cdot \mathrm{cm}^{-2}\right)$ presented the best results for wettability and roughness in almost all polyindoles. 

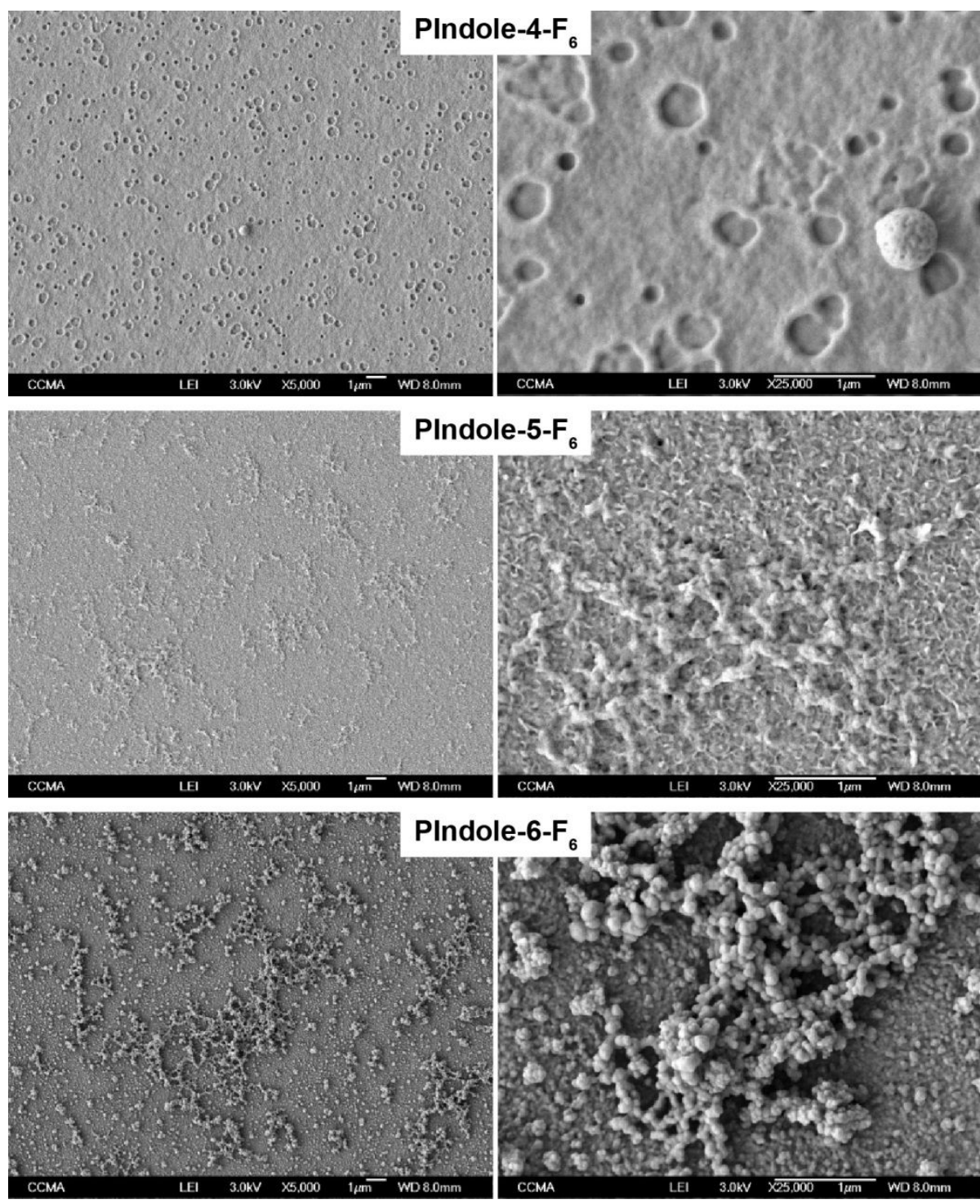

Figure 3: SEM images at two different magnifications (5000x and $25000 \times)$ of the polyindoles substituted with $\mathrm{C}_{6} \mathrm{~F}_{13}$ chains in the different positions.

Table 3: Dynamic water contact angles (hysteresis $H$ and sliding angle a) for PIndole-6- $\mathbf{F}_{6}$ as a function of the normalized deposition charge.

\begin{tabular}{ccc}
$\begin{array}{c}\text { normalized deposition } \\
\text { charge }\left(\mathrm{mC} \cdot \mathrm{cm}^{-2}\right)\end{array}$ & $H\left(^{\circ}\right)$ & $\alpha\left(^{\circ}\right)$ \\
\hline 12.5 & \multicolumn{2}{r}{ sticky behavior } \\
25 & \multicolumn{2}{r}{ sticky behavior } \\
50 & 2.1 & 20.6 \\
100 & 0.8 & 9.5
\end{tabular}

In order to explain the effects of the surface structures on the wetting properties, it is first necessary to prepare smooth substrates with each polymer and determine the contact angles $\left(\theta^{\mathrm{Y}}\right)$ for each probe liquid. These contact angles are dependent on the solid-vapor $\left(\gamma_{\mathrm{SV}}\right)$, solid-liquid $\left(\gamma_{\mathrm{SL}}\right)$ and liquid-vapor $\left(\gamma_{\mathrm{LV}}\right)$ surface tensions following the Young equation [35] $\left(\cos \theta^{\mathrm{Y}}=\left(\gamma_{S V}-\gamma_{S L}\right) / \gamma_{L V}\right)$. The smooth substrates were obtained by reducing the normalized deposition charge $(Q s)$ to $1 \mathrm{mC} \cdot \mathrm{cm}^{-2}$ in order to cover all the substrate by a very thin polymer layer while avoiding the formation of surface structures. The roughness and the apparent contact angles of these smooth substrates are given in Table 4 confirming their ultralow roughness and wettability. These results show that the polymers with $\mathrm{C}_{6} \mathrm{~F}_{13}$ fluorinated chains are intrinsically hydrophobic $\left(\theta^{\mathrm{Y}}\right.$ water $\left.>90^{\circ}\right)$ while the polymers with $\mathrm{C}_{4} \mathrm{~F}_{9}$ fluorinated chains as well as the polyindoles without fluorinated chain are slightly hydrophilic $\left(\theta^{\mathrm{Y}}{ }_{\text {water }}<90^{\circ}\right)$. As expected the polymers with $\mathrm{C}_{6} \mathrm{~F}_{13}$ fluorinated chains have also the highest oleophobicity even if the oil contact angles are relatively low. 

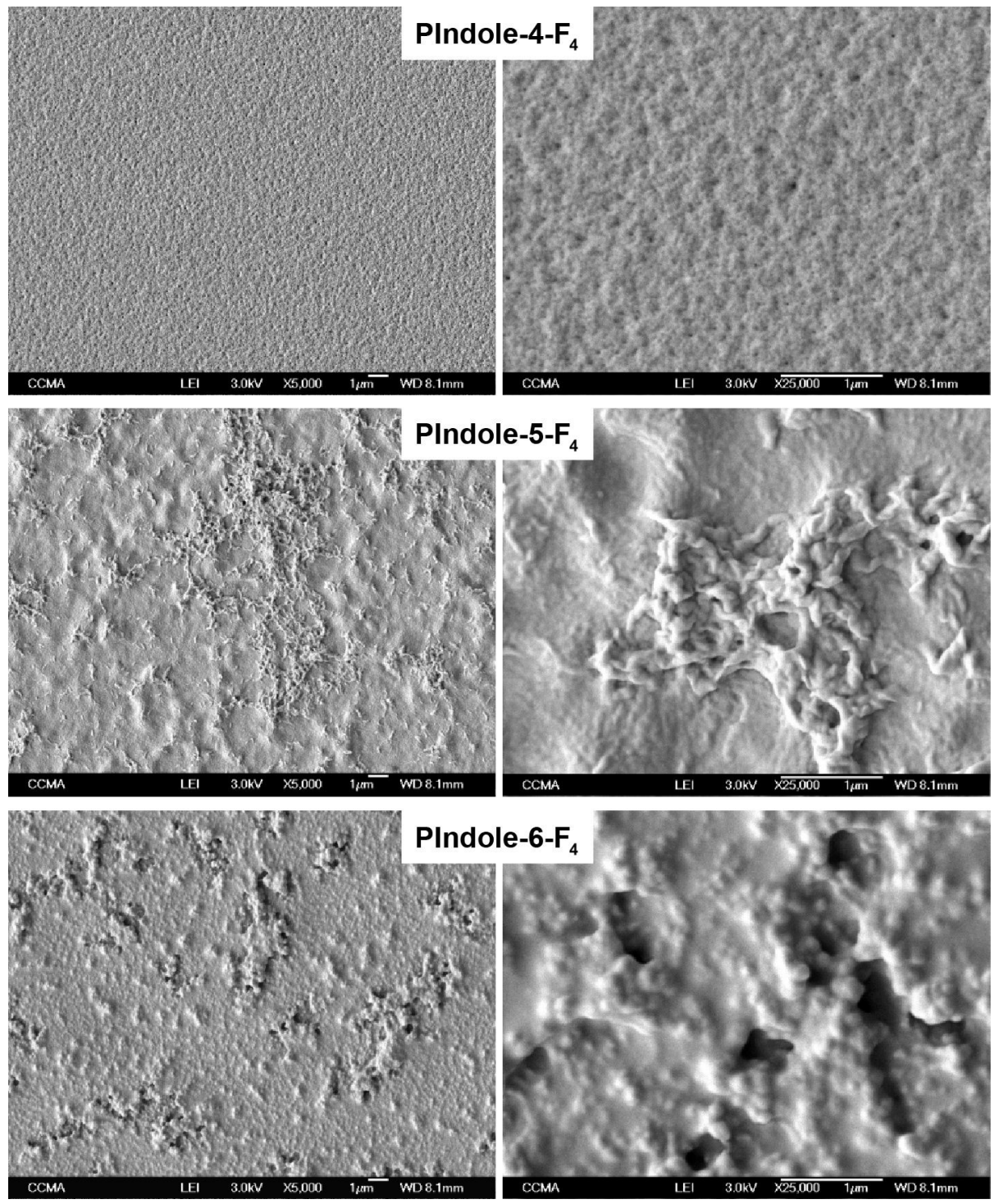

Figure 4: SEM images at two different magnifications $(5000 \times$ and $25000 \times)$ of the polyindoles substituted with $\mathrm{C}_{4} \mathrm{~F}_{9}$ chains in the different positions.

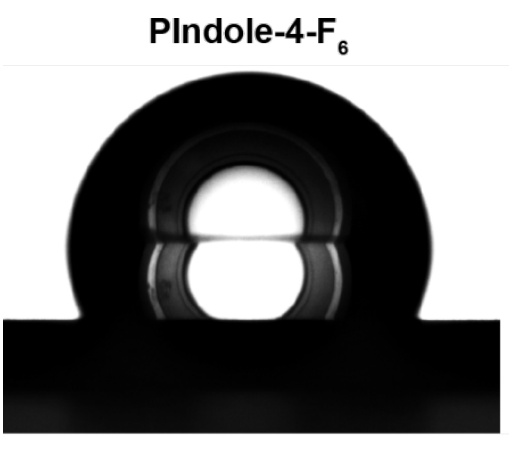

$109.9^{\circ}$

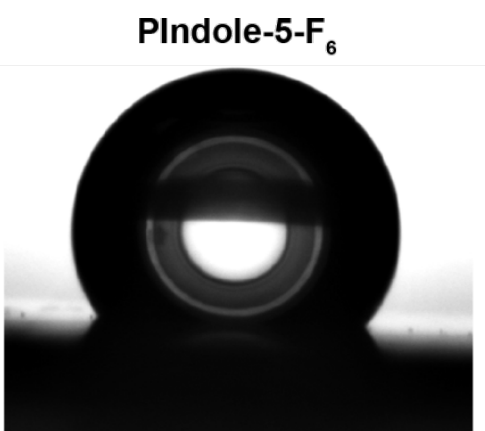

$124.8^{\circ}$

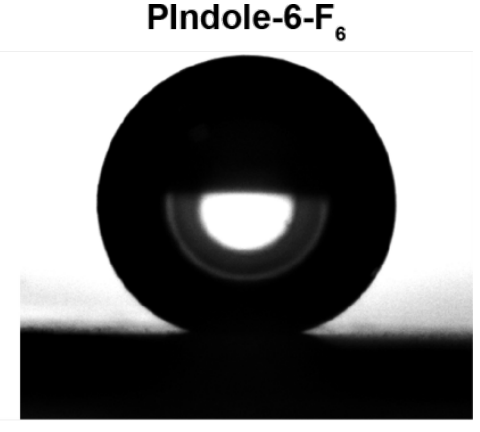

$158.9^{\circ}$

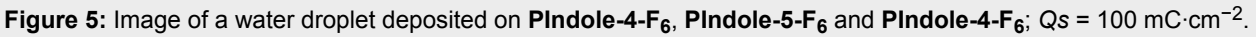


Table 4: Arithmetic roughness $\left(R_{\mathrm{a}}\right)$, quadratic roughness $\left(R_{\mathrm{q}}\right)$ and apparent contact angles $(\theta)$ for the four probe liquids (water, diiodomethane, sunflower oil and hexadecane) for the "smooth" polymers.

\begin{tabular}{|c|c|c|c|c|c|c|}
\hline polymer & $R_{\mathrm{a}}(\mathrm{nm})$ & $R_{\mathrm{q}}(\mathrm{nm})$ & $\theta_{\text {water }}^{Y}$ & $\theta_{\text {diiodomethane }}^{\mathrm{Y}}$ & $\theta_{\text {sunflower }}^{\mathrm{Y}}$ & $\theta_{\text {hexadecane }}^{Y}$ \\
\hline PIndole & 6.3 & 8.8 & 79.9 & 47.3 & 0 & 0 \\
\hline PIndole-4-F 6 & 6.6 & 9.5 & 97.5 & 51.3 & 41.5 & 25.6 \\
\hline PIndole-4-F 4 & 7.3 & 9.4 & 78.7 & 35.6 & 16.0 & 0 \\
\hline PIndole-5-F 6 & 6.4 & 9.8 & 96.8 & 60.4 & 47.3 & 37.9 \\
\hline PIndole-5-F 4 & 6.3 & 8.1 & 81.4 & 44.9 & 0 & 0 \\
\hline PIndole-6-F 6 & 6.8 & 9.5 & 99.4 & 66.8 & 50.7 & 44.1 \\
\hline PIndole-6-F 4 & 7.8 & 10.1 & 81.1 & 45.7 & 19.5 & 0 \\
\hline
\end{tabular}

Indeed, two equations (the Wenzel and the Cassie-Baxter equation) [36,37] depending on $\theta^{\mathrm{Y}}$ are very often used to explain the effect of the surface roughness on the wetting properties. In the Wenzel equation [36] $\left(\cos \theta=r \cdot \cos \theta^{\mathrm{Y}}\right.$, where $r$ is a roughness parameter), the surface roughness can increase $\theta$, but only if $\theta^{\mathrm{Y}}>90^{\circ}$. Hence, it is possible to have an extremely high $\theta_{\text {water }}$ but the contact angle hysteresis $(H)$ is usually high because the surface roughness increases also the solid-liquid interface and thereby, increasing the adhesion between the water drop and the surface. Only the Cassie-Baxter equation [37] $(\cos \theta=$ $r_{\mathrm{f}} f \cdot \cos \theta^{\mathrm{Y}}+f-1$, where $r_{\mathrm{f}}$ is the roughness ratio of the substrate wetted by the liquid, $f$ the solid fraction and $(1-f)$ the air fraction) can predict the superhydrophobicity of PIndole-6-F $\mathbf{F}_{\mathbf{6}}$, for example. Here, the presence of a high amount of air between the droplet and the substrate can lead to extremely high $\theta_{\text {water }}$ with a very low $H$. In the case of PIndole-6-F $\mathbf{6}$, the presence of the spherical nanoparticles formed on the surface during the polymerization allows to trap a high amount of air leading to superhydrophobic properties. These nanoparticles also induce a high increase of the surface oleophobicity, for example an increase of $\theta_{\text {hexadecane }}$ of $49.2^{\circ}$, from $44.1^{\circ}$ on the smooth surface to $99.3^{\circ}$ on the structured surface.

\section{Conclusion}

Here we report for the first time the possibility to obtain hydrophobic and superhydrophobic polymeric films with a very low roughness by electropolymerization of fluorinated indoles differing by the length $\left(\mathrm{C}_{4} \mathrm{~F}_{9}, \mathrm{C}_{6} \mathrm{~F}_{13}\right.$ and $\left.\mathrm{C}_{8} \mathrm{~F}_{17}\right)$ and the position (4, 5 and 6-position on indole) of the perfluorinated substituent. Polymeric films were obtained for $\mathrm{C}_{4} \mathrm{~F}_{9}$ and $\mathrm{C}_{6} \mathrm{~F}_{13}$ showing several differences mainly with the substituent position, affecting the surface morphology and the wetting properties. The best results were obtained with PIndole-6-F 6 for which a superhydrophobic state with a self-cleaning condition and highly oleophobic properties were reached due to the presence of spherical nanoparticles and the fluorinated compounds on the surface. This work opens new ways in the formation of superhydrophobic polyindoles films by electrodeposition for future applications.

\section{Experimental Monomer synthesis and characterization}

4-(aminomethyl)indole, 5-(aminomethyl)indole and 6-(aminomethyl)indole were purchased from Sigma-Aldrich. The monomers were synthesized by amidification between the corresponding (aminomethyl)indole and fluorinated acid (Scheme 2). More precisely, $0.26 \mathrm{~g}$ ( $1.4 \mathrm{mmol}, 1$ equiv) of $N$-(3-dimethylaminopropyl)- $N$ '-ethylcarbodiimide hydrochloride (EDC) and $0.17 \mathrm{~g}$ of 4-dimethylaminopyridine (DMAP) (1.4 mmol, 1 equiv) were added to $20 \mathrm{~mL}$ of dichloromethane containing 1 equiv of the corresponding fluorinated acid. After stirring for $30 \mathrm{~min}, 0.2 \mathrm{~g}$ ( $1.4 \mathrm{mmol}, 1$ equiv) of the corresponding (aminomethyl)indole was added. The solution was stirred at room temperature for $24 \mathrm{~h}$. The crude product was

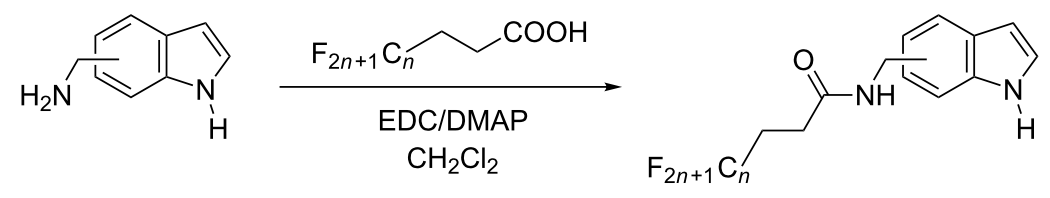


purified by column chromatography (stationary phase: silica gel; eluent: chloroform/methanol 95:5).

$N$-((1H-Indol-4-yl)methyl)-4,4,5,5,6,6,7,7,8,8,9,9,10,10,11,11, 11-heptadecafluoroundecanamide (Indole-4-F 8 ): Yield 15\%; yellow solid; mp $163.2{ }^{\circ} \mathrm{C} ;{ }^{1} \mathrm{H}$ NMR $\left(200 \mathrm{MHz}, \mathrm{CD}_{3} \mathrm{OD}\right) \delta$ $7.32(\mathrm{~d}, J=8.0 \mathrm{~Hz}, 1 \mathrm{H}), 7.24(\mathrm{~d}, J=3.2 \mathrm{~Hz}, 1 \mathrm{H}), 7.06(\mathrm{~m}, 1 \mathrm{H})$, $6.93(\mathrm{~d}, J=6.8 \mathrm{~Hz}, 1 \mathrm{H}), 6.51(\mathrm{dd}, J=3.2,0.9 \mathrm{~Hz}, 1 \mathrm{H}), 4.65(\mathrm{~s}$, 2H), $2.55(\mathrm{~m}, 4 \mathrm{H}) ;{ }^{19} \mathrm{~F}$ NMR (188 MHz, CD $\left.3 \mathrm{OD}\right) \delta-82.38(\mathrm{~m}$, $3 \mathrm{~F}),-115.74(\mathrm{~m}, 2 \mathrm{~F}),-122.87(\mathrm{~m}, 6 \mathrm{~F}),-123.75(\mathrm{~m}, 2 \mathrm{~F})$, $-124.52(\mathrm{~m}, 2 \mathrm{~F}),-127.29(\mathrm{~m}, 2 \mathrm{~F}) ;{ }^{13} \mathrm{C} \mathrm{NMR}(50 \mathrm{MHz}$, $\left.\mathrm{CD}_{3} \mathrm{OD}\right) \delta 172.45,137.84,130.34,128.04,125.64,122.22$, 119.39, 111.83, 100.41, 42.98, $28.1(\mathrm{t}, J=23.1 \mathrm{~Hz}), 27.62$ (t, $J=6.2 \mathrm{~Hz}) ; \mathrm{MS}(70 \mathrm{eV}) \mathrm{m} / z: \mathrm{M}^{+} 620(82), \mathrm{C}_{9} \mathrm{H}_{9} \mathrm{~N}_{2}{ }^{+\bullet} 145$ (100), $\mathrm{C}_{9} \mathrm{H}_{8} \mathrm{~N}^{+\bullet} 130$ (92), $\mathrm{C}_{8} \mathrm{H}_{8} \mathrm{~N}^{+} 118$ (52).

$N$-((1H-Indol-4-yl)methyl)-4,4,5,5,6,6,7,7,8,8,9,9,9-tridecafluorononanamide (Indole-4-F $\mathbf{F}_{\mathbf{6}}$ ): Yield 25\%; yellow solid; mp $150.2{ }^{\circ} \mathrm{C} ;{ }^{1} \mathrm{H}$ NMR $\left(200 \mathrm{MHz}, \mathrm{CD}_{3} \mathrm{OD}\right) \delta 7.32(\mathrm{~d}, J=8.0$ $\mathrm{Hz}, 1 \mathrm{H}), 7.24(\mathrm{~d}, J=3.2 \mathrm{~Hz}, 1 \mathrm{H}), 7.06(\mathrm{~m}, 1 \mathrm{H}), 6.92(\mathrm{~d}, J=7.0$ $\mathrm{Hz}, 1 \mathrm{H}), 6.50(\mathrm{dd}, J=3.2,0.9 \mathrm{~Hz}, 1 \mathrm{H}), 4.65(\mathrm{~s}, 2 \mathrm{H}), 2.55$ (m, $4 \mathrm{H}) ;{ }^{19} \mathrm{~F}$ NMR $\left(188 \mathrm{MHz}, \mathrm{CD}_{3} \mathrm{OD}\right) \delta-82.43(\mathrm{~m}, 3 \mathrm{~F}),-115.74$ $(\mathrm{m}, 2 \mathrm{~F}),-122.93(\mathrm{~m}, 2 \mathrm{~F}),-123.91(\mathrm{~m}, 2 \mathrm{~F}),-124.60(\mathrm{~m}, 2 \mathrm{~F})$, $-127.36(\mathrm{~m}, 2 \mathrm{~F}) ;{ }^{13} \mathrm{C}$ NMR $\left(50 \mathrm{MHz}, \mathrm{CD}_{3} \mathrm{OD}\right) \delta 172.43$, 137.81, 130.32, 128.04, 125.64, 122.22, 119.38, 111.82, 100.41, 42.98, $27.90(\mathrm{t}, J=22.5 \mathrm{~Hz}), 27.47(\mathrm{t}, J=2.8 \mathrm{~Hz})$; $\mathrm{MS}(70 \mathrm{eV})$ $m / z: \mathrm{M}^{+} 520$ (25), $\mathrm{C}_{9} \mathrm{H}_{9} \mathrm{~N}_{2}^{+\bullet} 145$ (100), $\mathrm{C}_{9} \mathrm{H}_{8} \mathrm{~N}^{+\bullet} 130$ (87), $\mathrm{C}_{8} \mathrm{H}_{8} \mathrm{~N}^{+} 118$ (59).

$N$-((1H-Indol-4-yl)methyl)-4,4,5,5,6,6,7,7,8,8,8-undecafluorooctanamide (Indole-4-F 4 ): Yield 21\%; yellow solid; mp $139.8{ }^{\circ} \mathrm{C} ;{ }^{1} \mathrm{H}$ NMR $\left(200 \mathrm{MHz}, \mathrm{CD}_{3} \mathrm{OD}\right) \delta 7.32(\mathrm{~d}, J=8.1 \mathrm{~Hz}$, $1 \mathrm{H}), 7.24(\mathrm{~d}, J=3.2 \mathrm{~Hz}, 1 \mathrm{H}), 7.06(\mathrm{~m}, 1 \mathrm{H}), 6.93(\mathrm{~d}, J=7.6 \mathrm{~Hz}$, $1 \mathrm{H}), 6.50$ (dd, $J=3.2,0.9 \mathrm{~Hz}, 1 \mathrm{H}), 4.65(\mathrm{~s}, 2 \mathrm{H}), 2.55(\mathrm{~m}, 4 \mathrm{H})$; ${ }^{19} \mathrm{~F}$ NMR (188 MHz, CD $\left.\mathrm{CD}_{3} \mathrm{OD}\right) \delta-82.69(\mathrm{~m}, 3 \mathrm{~F}),-115.98(\mathrm{~m}$, $2 \mathrm{~F}),-125.63(\mathrm{~m}, 2 \mathrm{~F}),-127.31(\mathrm{~m}, 2 \mathrm{~F}) ;{ }^{13} \mathrm{C} \mathrm{NMR}(50 \mathrm{MHz}$, $\left.\mathrm{CD}_{3} \mathrm{OD}\right) \delta 172.37,137.75,130.26,127.98,125.58,122.16$, 119.32, 111.76, 100.35, 42.91, $27.82(\mathrm{t}, J=22.1 \mathrm{~Hz}), 27.50$ (t, $J=4.0 \mathrm{~Hz})$; MS (70 eV) m/z: $\mathrm{M}^{+} 420(40), \mathrm{C}_{9} \mathrm{H}_{9} \mathrm{~N}_{2}{ }^{+\bullet} 145(95)$, $\mathrm{C}_{9} \mathrm{H}_{8} \mathrm{~N}^{+\bullet} 130$ (100), $\mathrm{C}_{8} \mathrm{H}_{8} \mathrm{~N}^{+} 118$ (65).

$N$-((1H-Indol-5-yl)methyl)-4,4,5,5,6,6,7,7,8,8,9,9,10,10,11,11, 11-heptadecafluoroundecanamide (Indole-5-F $)$ : Yield 28\%; yellow solid; mp $135.9{ }^{\circ} \mathrm{C} ;{ }^{1} \mathrm{H}$ NMR (200 MHz, $\left.\mathrm{CD}_{3} \mathrm{OD}\right) \delta$ 7.47 (s, 1H), 7.33 (d, $J=8.4 \mathrm{~Hz}, 1 \mathrm{H}), 7.21$ (d, $J=3.1 \mathrm{~Hz}, 1 \mathrm{H})$, $7.04(\mathrm{dd}, J=8.4,1.6 \mathrm{~Hz}, 1 \mathrm{H}), 6.40(\mathrm{dd}, J=3.1,0.8 \mathrm{~Hz}, 1 \mathrm{H})$, $4.49(\mathrm{~s}, 2 \mathrm{H}), 2.53(\mathrm{~m}, 4 \mathrm{H}) ;{ }^{19} \mathrm{~F} \mathrm{NMR}\left(188 \mathrm{MHz}, \mathrm{CD}_{3} \mathrm{OD}\right) \delta$ $-82.40(\mathrm{~m}, 3 \mathrm{~F}),-115.74(\mathrm{~m}, 2 \mathrm{~F}),-122.90(\mathrm{~m}, 6 \mathrm{~F}),-123.77$ (m, $2 \mathrm{~F}),-124.60(\mathrm{~m}, 2 \mathrm{~F}),-127.36(\mathrm{~m}, 2 \mathrm{~F}) ;{ }^{13} \mathrm{C} \mathrm{NMR}(50 \mathrm{MHz}$, $\left.\mathrm{CD}_{3} \mathrm{OD}\right) \delta 172.32,137.03,129.90,129.53,126.06,122.45$, 120.51, 112.24, 102.24, 45.09, $27.82(\mathrm{t}, J=21.4 \mathrm{~Hz}), 27.53$ (t,
$J=4.1 \mathrm{~Hz}) ; \mathrm{MS}(70 \mathrm{eV}) \mathrm{m} / z: \mathrm{M}^{+} 620$ (4), $\mathrm{C}_{9} \mathrm{H}_{9} \mathrm{~N}_{2}^{+\bullet} 145$ (100), $\mathrm{C}_{9} \mathrm{H}_{8} \mathrm{~N}^{+} \cdot 130$ (92), $\mathrm{C}_{8} \mathrm{H}_{8} \mathrm{~N}^{+} 118$ (47).

$N$-((1H-Indol-5-yl)methyl)-4,4,5,5,6,6,7,7,8,8,9,9,9-tridecafluorononanamide (Indole-5-F $\mathbf{6}$ ): Yield 51\%; yellow solid; mp $85.5^{\circ} \mathrm{C} ;{ }^{1} \mathrm{H}$ NMR $\left(200 \mathrm{MHz}, \mathrm{CD}_{3} \mathrm{OD}\right) \delta 7.47(\mathrm{~s}, 1 \mathrm{H}), 7.33$ $(\mathrm{d}, J=8.3 \mathrm{~Hz}, 1 \mathrm{H}), 7.21(\mathrm{~d}, J=3.1 \mathrm{~Hz}, 1 \mathrm{H}), 7.03(\mathrm{dd}, J=8.3$, $1.6 \mathrm{~Hz}, 1 \mathrm{H}), 6.40(\mathrm{dd}, J=3.1 \mathrm{~Hz}, 0.8 \mathrm{~Hz}, 1 \mathrm{H}), 4.44(\mathrm{~s}, 2 \mathrm{H})$, $2.47(\mathrm{~m}, 4 \mathrm{H}) ;{ }^{19} \mathrm{~F}$ NMR $\left(188 \mathrm{MHz}, \mathrm{CD}_{3} \mathrm{OD}\right) \delta-82.45(\mathrm{~m}, 3 \mathrm{~F})$, $-115.74(\mathrm{~m}, 2 \mathrm{~F}),-122.95(\mathrm{~m}, 2 \mathrm{~F}),-123.93(\mathrm{~m}, 2 \mathrm{~F}),-124.60$ $(\mathrm{m}, 2 \mathrm{~F}),-127.36(\mathrm{~m}, 2 \mathrm{~F}) ;{ }^{13} \mathrm{C}$ NMR $\left(50 \mathrm{MHz}, \mathrm{CD}_{3} \mathrm{OD}\right) \delta$ $172.38,137.10,129.97,129.61,126.13,122.52,120.58,112.31$, 102.31, 45.16, $27.86(\mathrm{t}, J=22.8 \mathrm{~Hz}), 27.60(\mathrm{t}, J=3.0 \mathrm{~Hz})$; MS (70 eV) $m / z: \mathrm{M}^{+} 520$ (35), $\mathrm{C}_{9} \mathrm{H}_{9} \mathrm{~N}_{2}^{+\bullet} 145$ (100), $\mathrm{C}_{9} \mathrm{H}_{8} \mathrm{~N}^{+\bullet} 130$ (90), $\mathrm{C}_{8} \mathrm{H}_{8} \mathrm{~N}^{+} 118$ (54).

$N$-((1H-Indol-5-yl)methyl)-4,4,5,5,6,6,7,7,8,8,8-undecafluorooctanamide (Indole-5- $\mathbf{F}_{4}$ ): Yield $61 \%$; yellow solid; $\mathrm{mp}$ $47.7{ }^{\circ} \mathrm{C}$; ${ }^{1} \mathrm{H}$ NMR $\left(200 \mathrm{MHz}, \mathrm{CD}_{3} \mathrm{OD}\right) \delta 7.47(\mathrm{~s}, 1 \mathrm{H}), 7.33(\mathrm{~d}$, $J=8.4 \mathrm{~Hz}, 1 \mathrm{H}), 7.21(\mathrm{~d}, J=3.1 \mathrm{~Hz}, 1 \mathrm{H}), 7.04(\mathrm{dd}, J=8.4$, $1.6 \mathrm{~Hz}, 1 \mathrm{H}), 6.40(\mathrm{dd}, J=3.1,0.8 \mathrm{~Hz}, 1 \mathrm{H}), 4.44(\mathrm{~s}, 2 \mathrm{H}), 2.47$ $(\mathrm{m}, 4 \mathrm{H}) ;{ }^{19} \mathrm{~F}$ NMR $\left(188 \mathrm{MHz}, \mathrm{CD}_{3} \mathrm{OD}\right) \delta-82.67$ (m, 3F), -115.97 (m, 2F), -125.60 (m, 2F), -127.21 (m, 2F); ${ }^{13} \mathrm{C}$ NMR (50 MHz, $\left.\mathrm{CD}_{3} \mathrm{OD}\right) \delta 172.32,137.03,129.91,129.54,126.07$, 122.45, 120.52, 112.24, 102.25, 45.09, $27.78(\mathrm{t}, J=22.5 \mathrm{~Hz})$, $27.64(\mathrm{t}, J=3.9 \mathrm{~Hz})$; $\mathrm{MS}(70 \mathrm{eV}) \mathrm{m} / z: \mathrm{M}^{+} 420(98), \mathrm{C}_{9} \mathrm{H}_{9} \mathrm{~N}_{2}{ }^{+\bullet}$ 145 (90), $\mathrm{C}_{9} \mathrm{H}_{8} \mathrm{~N}^{+\bullet} 130$ (100), $\mathrm{C}_{8} \mathrm{H}_{8} \mathrm{~N}^{+} 118$ (70).

$N$-((1H-Indol-6-yl)methyl)-4,4,5,5,6,6,7,7,8,8,9,9,10,10,11,11, 11-heptadecafluoroundecanamide (Indole-6-F $\mathbf{F}_{\mathbf{8}}$ ): Yield 30\%; yellow solid; mp $121.0{ }^{\circ} \mathrm{C}$; ${ }^{1} \mathrm{H}$ NMR $\left(200 \mathrm{MHz}, \mathrm{CD}_{3} \mathrm{OD}\right) \delta$ 7.49 (d, $J=8.1 \mathrm{~Hz}, 1 \mathrm{H}), 7.32$ (s, 1H), 7.20 (d, $J=3.1 \mathrm{~Hz}, 1 \mathrm{H})$, $6.95(\mathrm{dd}, J=8.1,1.4 \mathrm{~Hz}, 1 \mathrm{H}), 6.40(\mathrm{dd}, J=3.1,0.8 \mathrm{~Hz}, 1 \mathrm{H})$, $4.45(\mathrm{~s}, 2 \mathrm{H}), 2.56(\mathrm{~m}, 4 \mathrm{H}) ;{ }^{19} \mathrm{~F} \mathrm{NMR}\left(188 \mathrm{MHz}, \mathrm{CD}_{3} \mathrm{OD}\right) \delta$ $-82.39(\mathrm{~m}, 3 \mathrm{~F}),-115.76(\mathrm{~m}, 2 \mathrm{~F}),-122.86(\mathrm{~m}, 6 \mathrm{~F}),-123.78(\mathrm{~m}$, $2 \mathrm{~F}),-124.58(\mathrm{~m}, 2 \mathrm{~F}),-127.29(\mathrm{~m}, 2 \mathrm{~F}) ;{ }^{13} \mathrm{C} \mathrm{NMR}(50 \mathrm{MHz}$, $\left.\mathrm{CD}_{3} \mathrm{OD}\right) \delta 172.36,137.73,132.46,128.79,125.87,121.30$, 120.22, 111.47, 102.17, 45.10, $27.79(\mathrm{t}, J=21.0 \mathrm{~Hz}), 27.43(\mathrm{t}$, $J=5.0 \mathrm{~Hz}$ ); MS (70 eV) m/z: $\mathrm{M}^{+} 620$ (4), $\mathrm{C}_{9} \mathrm{H}_{9} \mathrm{~N}_{2}{ }^{+\bullet} 145$ (100), $\mathrm{C}_{9} \mathrm{H}_{8} \mathrm{~N}^{+\bullet} 130$ (97), $\mathrm{C}_{8} \mathrm{H}_{8} \mathrm{~N}^{+} 118$ (45).

$N$-((1H-Indol-6-yl)methyl)-4,4,5,5,6,6,7,7,8,8,9,9,9-tridecafluorononanamide (Indole-6-F $)$ ): Yield 19\%; yellow solid; mp $120.7{ }^{\circ} \mathrm{C} ;{ }^{1} \mathrm{H}$ NMR $\left(200 \mathrm{MHz}, \mathrm{CD}_{3} \mathrm{OD}\right) \delta 7.49$ (d, $J=8.1$ $\mathrm{Hz}, 1 \mathrm{H}), 7.31(\mathrm{~s}, 1 \mathrm{H}), 7.20(\mathrm{~d}, J=3.1 \mathrm{~Hz}, 1 \mathrm{H}), 6.94(\mathrm{dd}, J=$ $8.1,1.5 \mathrm{~Hz}, 1 \mathrm{H}), 6.40(\mathrm{dd}, J=3.1,0.8 \mathrm{~Hz}, 1 \mathrm{H}), 4.45(\mathrm{~s}, 2 \mathrm{H})$, $2.47(\mathrm{~m}, 4 \mathrm{H}) ;{ }^{19} \mathrm{~F}$ NMR $\left(188 \mathrm{MHz}, \mathrm{CD}_{3} \mathrm{OD}\right) \delta-82.45(\mathrm{~m}, 3 \mathrm{~F})$, $-115.77(\mathrm{~m}, 2 \mathrm{~F}),-122.95(\mathrm{~m}, 2 \mathrm{~F}),-123.93(\mathrm{~m}, 2 \mathrm{~F}),-124.60$ $(\mathrm{m}, 2 \mathrm{~F}),-127.36(\mathrm{~m}, 2 \mathrm{~F}) ;{ }^{13} \mathrm{C}$ NMR (50 MHz, CD $\left.3 \mathrm{OD}\right) \delta$ $172.43,137.80,132.52,128.86,125.93,121.36,120.28,111.54$, $102.23,45.15,27.88(\mathrm{t}, J=21.0 \mathrm{~Hz}), 27.58(\mathrm{t}, J=3.5 \mathrm{~Hz})$; MS 
$(70 \mathrm{eV}) \mathrm{m} / \mathrm{z}: \mathrm{M}^{+} 520(40), \mathrm{C}_{9} \mathrm{H}_{9} \mathrm{~N}_{2}^{+\bullet} 145$ (100), $\mathrm{C}_{9} \mathrm{H}_{8} \mathrm{~N}^{+\bullet} 130$ (94), $\mathrm{C}_{8} \mathrm{H}_{8} \mathrm{~N}^{+} 118$ (53).

$N$-((1H-Indol-6-yl)methyl)-4,4,5,5,6,6,7,7,8,8,8-undecafluorooctanamide (Indole-6-F $\mathbf{F}_{4}$ ): Yield 33\%; yellow solid; $\mathrm{mp}$ $105.7{ }^{\circ} \mathrm{C}$; ${ }^{1} \mathrm{H}$ NMR $\left(200 \mathrm{MHz}, \mathrm{CD}_{3} \mathrm{OD}\right) \delta 7.50(\mathrm{~d}, J=8.1 \mathrm{~Hz}$, $1 \mathrm{H}), 7.31(\mathrm{~s}, 1 \mathrm{H}), 7.20(\mathrm{~d}, J=3.2 \mathrm{~Hz}, 1 \mathrm{H}), 6.95$ (dd, $J=8.1$, $1.5 \mathrm{~Hz}, 1 \mathrm{H}), 6.40(\mathrm{dd}, J=3.1,0.8 \mathrm{~Hz}, 1 \mathrm{H}), 4.45(\mathrm{~s}, 2 \mathrm{H}), 2.58$ $(\mathrm{m}, 4 \mathrm{H}) ;{ }^{19} \mathrm{~F}$ NMR $\left(188 \mathrm{MHz}, \mathrm{CD}_{3} \mathrm{OD}\right) \delta-82.66(\mathrm{~m}, 3 \mathrm{~F})$, $-115.91(\mathrm{~m}, 2 \mathrm{~F}),-125.60(\mathrm{~m}, 2 \mathrm{H}),-127.27(\mathrm{~m}, 2 \mathrm{H}) ;{ }^{13} \mathrm{C} \mathrm{NMR}$ $\left(50 \mathrm{MHz}, \mathrm{CD}_{3} \mathrm{OD}\right) \delta 172.43,137.72,132.45,128.78,125.87$, $121.29,120.21,111.47,102.21,45.08,27.72(\mathrm{t}, J=21.0 \mathrm{~Hz})$, $27.56(\mathrm{t}, J=4.0 \mathrm{~Hz})$; $\mathrm{MS}(70 \mathrm{eV}) \mathrm{m} / z: \mathrm{M}^{+} 420(85), \mathrm{C}_{9} \mathrm{H}_{9} \mathrm{~N}_{2}{ }^{+\bullet}$ 145 (85), $\mathrm{C}_{9} \mathrm{H}_{8} \mathrm{~N}^{+\bullet} 130$ (100), $\mathrm{C}_{8} \mathrm{H}_{8} \mathrm{~N}^{+} 118$ (70).

\section{Electrodeposition parameters}

The polyindole films were electrodeposited by using a potentiostat (Autolab). For this, $2 \mathrm{~cm}^{2}$ gold plates were chosen as working electrode, a carbon rod as counter-electrode while saturated calomel (SCE) was taken as reference electrode. The electrolyte used was a $0.1 \mathrm{~mol}$ solution of tetrabutylammonium perchlorate $\left(\mathrm{Bu}_{4} \mathrm{NClO}_{4}\right)$ in anhydrous acetonitrile. Before the electrodeposition, the solution was degassed under argon and $0.01 \mathrm{~mol}$ of monomer was introduced. After the electrodeposition, the coated substrates were washed three times in acetonitrile and slowly dried.

\section{Polymer and surface characterization}

The surface roughness (arithmetic $R_{\mathrm{a}}$ and quadratic $R_{\mathrm{q}}$ ) were determined by using a Wyko NT 1100 optical microscope of Bruker. The data were obtained using the High Mag Phase Shift Interference (PSI) working mode, the objective $50 \times$ and the field of view (FOV) $0.5 \times$.

The scanning electron microscopy images were obtained by using a $6700 \mathrm{~F}$ microscope of JEOL.

The contact angles were determined by using a DSA30 goniometer of Krüss. Liquids of different surface tension were chosen to characterize the surface hydrophobicity and oleophobicity: water $\left(\gamma_{\mathrm{LV}}=72.8 \mathrm{mN} \cdot \mathrm{m}^{-1}\right)$, diiodomethane $\left(\gamma_{\mathrm{LV}}=\right.$ $\left.50.0 \mathrm{mN} \cdot \mathrm{m}^{-1}\right)$, sunflower oil $\left(\gamma_{\mathrm{LV}} \approx 31 \mathrm{mN} \cdot \mathrm{m}^{-1}\right)$ and hexadecane $\left(\gamma_{\mathrm{LV}}=27.6 \mathrm{mN} \cdot \mathrm{m}^{-1}\right)$. The apparent contact angles $(\theta)$ were obtained by taken the angle at the triple point of a liquid droplet put on the substrate. The contact angle hysteresis $(H)$ and sliding angle $(\alpha)$ were determined with the tilted-drop method. Here, a $6 \mu \mathrm{L}$ liquid droplet was put on the substrate and the substrate was inclined until the droplet moving. The maximum inclination angle is $\alpha$. The advanced $\left(\theta_{\mathrm{adv}}\right)$ and receding $\left(\theta_{\text {rec }}\right)$ contact angles and by deduction the hysteresis $H=\theta_{\mathrm{adv}}-\theta_{\mathrm{rec}}$ were taken just before the moving of the droplet, the angle in the moving direction being $\theta_{\mathrm{adv}}$ and that in the opposite direction $\theta_{\text {rec }}$.

\section{Acknowledgements}

This work was supported by CNPq, Conselho Nacional de Desenvolvimento Científico e Tecnológico - Brazil (Process No. 202280/2014-4). We thank Jean-Pierre Laugier (CCMA, UNS) for the SEM images.

\section{References}

1. Liu, M.; Zheng, Y.; Zhai, J.; Jiang, L. Acc. Chem. Res. 2010, 43, 368-377. doi:10.1021/ar900205g

2. Simpson, J. T.; Hunter, S. R.; Aytug, T. Rep. Prog. Phys. 2015, 78, 086501. doi:10.1088/0034-4885/78/8/086501

3. Si, Y.; Guo, Z. Nanoscale 2015, 7, 5922-5946. doi:10.1039/C4NR07554D

4. Nishimoto, S.; Bhushan, B. RSC Adv. 2013, 3, 671-690. doi:10.1039/c2ra21260a

5. Rahmawan, Y.; Xu, L.; Yang, S. J. Mater. Chem. A 2013, 1, 2955-2969. doi:10.1039/C2TA00288D

6. Wang, J.-N.; Zhang, Y.-L.; Liu, Y.; Zheng, W.; Lee, L. P.; Sun, H.-B. Nanoscale 2015, 7, 7101-7114. doi:10.1039/C5NR00719D

7. Darmanin, T.; Guittard, F. Mater. Today 2015, 18, 273-285. doi:10.1016/j.mattod.2015.01.001

8. Koch, K.; Bhushan, B.; Barthlott, W. Prog. Mater. Sci. 2009, 54, 137-178. doi:10.1016/j.pmatsci.2008.07.003

9. Sun, M.; Watson, G. S.; Zheng, Y.; Watson, J. A.; Liang, A. J. Exp. Biol. 2009, 212, 3148-3155. doi:10.1242/jeb.033373

10. Bush, J. W. M.; Hu, D. L.; Prakash, M. Adv. Insect Physiol. 2007, 34, 117-192. doi:10.1016/S0065-2806(07)34003-4

11. Ju, J.; Bai, H.; Zheng, Y.; Zhao, T.; Fang, R.; Jiang, L. Nat. Commun. 2012, 3, 1247. doi:10.1038/ncomms2253

12. Andrews, H. G.; Eccles, E. A.; Schofield, W. C. E.; Badyal, J. P. S. Langmuir 2011, 27, 3798-3802. doi:10.1021/la2000014

13. Sarkar, A.; Kietzig, A.-M. Soft Matter 2015, 11, 1998-2007. doi:10.1039/C4SM02787F

14. Cha, T.-G.; Yi, J. W.; Moon, M.-W.; Lee, K.-R.; Kim, H.-Y. Langmuir 2010, 26, 8319-8326. doi:10.1021/la9047402

15. Huovinen, E.; Takkunen, L.; Korpela, T.; Suvanto, M.; Pakkanen, T. T.; Pakkanen, T. A. Langmuir 2014, 30, 1435-1443. doi:10.1021/la404248d

16. Beaujuge, P. M.; Reynolds, J. R. Chem. Rev. 2010, 110, 268-320. doi:10.1021/cr900129a

17. Xu, L.; Chen, Z.; Chen, W.; Mulchandani, A.; Yan, Y. Macromol. Rapid Commun. 2008, 29, 832-838. doi:10.1002/marc.200700891

18. Taleb, S.; Darmanin, T.; Guittard, F. ACS Appl. Mater. Interfaces 2014, 6, 7953-7960. doi:10.1021/am501279h

19. Santos, J. L.; Li, Y.; Culver, H. R.; Yu, M. S.; Herrera-Alonso, M. Chem. Commun. 2014, 50, 15045-15048. doi:10.1039/C4CC06056C

20. Pringle, J. M.; Ngamna, O.; Chen, J.; Wallace, G. G.; Forsyth, M.; MacFarlane, D. R. Synth. Met. 2006, 156, 979-983. doi:10.1016/j.synthmet.2006.06.009

21. D’Arcy, J. M.; Tran, H. D.; Tung, V. C.; Tucker-Schwartz, A. K.; Wong, R. P.; Yang, Y.; Kaner, R. B. Proc. Natl. Acad. Sci. U. S. A. 2010, 107, 19673-19678. doi:10.1073/pnas.1008595107

22. Chiou, N.-R.; Lu, C.; Guan, J.; Lee, L. J.; Epstein, A. J. Nat. Nanotechnol. 2007, 2, 354-357. doi:10.1038/nnano.2007.147 
23. Im, S. G.; Yoo, P. J.; Hammond, P. T.; Gleason, K. K. Adv. Mater. 2007, 19, 2863-2867. doi:10.1002/adma.200701170

24. Vucaj, N.; Quinn, M. D. J.; Baechler, C.; Notley, S. M.; Cottis, P.; Hojati-Talemi, P.; Fabretto, M. V.; Wallace, G. G.; Murphy, P. J.; Evans, D. R. Chem. Mater. 2014, 26, 4207-4213. doi:10.1021/cm5014653

25. Tarrade, J.; Darmanin, T.; Taffin de Givenchy, E.; Guittard, F.; Debarnot, D.; Poncin-Epaillard, F. Appl. Surf. Sci. 2014, 292, 782-789. doi:10.1016/j.apsusc.2013.12.051

26. Poverenov, E.; Li, M.; Bitler, A.; Bendikov, M. Chem. Mater. 2010, 22, 4019-4025. doi:10.1021/cm100561d

27. Darmanin, T.; Guittard, F. Adv. Mater. Interfaces 2015, 2, 1500081/1-1500081/7. doi:10.1002/admi.201500081

28. Mortier, C.; Darmanin, T.; Guittard, F. Macromolecules 2015, 48, 5188-5195. doi:10.1021/acs.macromol.5b01054

29. Yan, H.; Kurogi, K.; Mayama, H.; Tsujii, K. Angew. Chem., Int. Ed. 2005, 44, 3453-3456. doi:10.1002/anie.200500266

30. Mortier, C.; Darmanin, T.; Guittard, F. Adv. Eng. Mater. 2014, 16, 1400-1405. doi:10.1002/adem.201400212

31. Singh, V.; Chauhan, D. S.; Pandey, P. C. A comparative study on electrochemical synthesis of carboxylic acid substituted indoles and their application in selective oxidation of dopamine.. IEEE Sensors 2009, Christchurch, New Zealand, Oct 25-28, 2009; pp 1140-1144. doi:10.1109/ICSENS.2009.5398578

32. Ma, X.; Zhou, W.; Mo, D.; Wang, Z.; Xu, J. Synth. Met. 2015, 203, 98-106. doi:10.1016/j.synthmet.2015.02.025

33. Yakhmi, J. V.; Saxena, V.; Aswal, D. K. Conducting Polymer Sensors, Actuators and Field-Effect Transistors. Functional Materials: Preparation, Processing and Applications; Elsevier, 2012; pp 61-110. doi:10.1016/B978-0-12-385142-0.00002-7

34. Mortier, C.; Darmanin, T.; Guittard, F. ChemPlusChem 2014, 79 1434-1439. doi:10.1002/cplu.201402187

35. Young, T. Philos. Trans. R. Soc. London 1805, 95, 65-87. doi:10.1098/rstl.1805.0005

36. Wenzel, R. N. Ind. Eng. Chem. 1936, 28, 988-994. doi:10.1021/ie50320a024

37. Cassie, A. B. D.; Baxter, S. Trans. Faraday Soc. 1944, 40, 546-551. doi:10.1039/tf9444000546

\section{License and Terms}

This is an Open Access article under the terms of the Creative Commons Attribution License (http://creativecommons.org/licenses/by/2.0), which permits unrestricted use, distribution, and reproduction in any medium, provided the original work is properly cited.

The license is subject to the Beilstein Journal of Nanotechnology terms and conditions: (http://www.beilstein-journals.org/bjnano)

The definitive version of this article is the electronic one which can be found at: doi:10.3762/bjnano.6.212 